\title{
OBSERVATIONS ON THE LITURGICAL PSALTER IN MS CANON. LITURG. 172 (BODLEIAN LIBRARY, OXFORD)
}

This paper examines presentational and textual peculiarities of the liturgical psalter in the breviary contained in the Glagolitic MS Canon. liturg. 172 in the Bodleian Library. It argues that they demonstrate a heavy reliance on memorization of text, seem to reflect distinctive liturgical practice, and imply that the manuscript was written for a specific user.

Key w ords: breviary, banalizations, canticles, office hymns, liturgical psalter, reminiscences

\section{INTRODUCTION}

The Glagolitic codex MS Canon. Liturg. 172 in the Bodleian Library has attracted little scholarly attention, and that little has focussed mainly on the problem of its dating. The aim of this paper is to argue that the ostensibly defective character of its contents, which has made it seem a source of minor importance, in fact offers interesting clues to its intended and actual use.

\subsection{Dating}

The manuscript is supplied with a date at the end of the colophon on f. 409r: Dovaršens lito .c.t.i., i.e. in 1310. However, the reliability of this information is highly questionable. The date itself has been added in a different hand from that of the colophon or indeed from those found elsewhere in the manuscript, and it is written, apparently over black lettering, in a dull red ink which again is different from that used for rubrication (DU FEU 1971: plate). Tadin's attempt to vindicate a date early in the 14th century (TADIN 1953: 153-155) 
was refuted by Hamm, who pointed out textual parallels with manuscripts of the 15th century (HAMM 1953: 118-119). More recent research has produced supplementary evidence in favour of a later dating (BADURINA STIPČEVIĆ 2006: 32; BADURINA STIPČEVIĆ 2009: 12; BADURINA STIPČEVIĆ 2010: 47-49), and this is further supported by the visual appearance of the manuscript: its ornamental initials have analogues from the early 15 th century, e.g. at the beginning of the Pašmanski brevijar (ŠTEFANIĆ 1970: plate 27).

\subsection{Contents and physical appearance}

The manuscript belongs to a small number of liturgical compendia which combine breviary, missal and ritual: the codices Paris slav. 11 and Kopitar 22 and the 1493 and 1561 printings by Baromić and Brozić (VAJS 1915: 571-574; VAJS 1910: xxxii-xxxvii, xciii-c; VAJS 1948: 39-43, 52-55). Although it has been rebound, and may have lost a folio or folios at the beginning, it is otherwise intact; its 411 folios have apparently not been trimmed, as prickmarks are still visible down some outer edges, and so its dimensions, $15 \times 10.2 \mathrm{~cm}$, are probably original. It is thus comparable in size to the items listed above: Paris slav. 11 measures $11 \times 17 \mathrm{~cm}$, Kopitar $2218 \times 12 \mathrm{~cm}$, and the two printings are in $16^{0}$ format (VAJS 1948: 40, 42, 52; GRABAR 1984: 178). The inference that such books were intended for individual use by clerics who had occasion to move from place to place (GRABAR 1984: 159-160) is supported in the case of $M S 172$ by the page layout and lettering: the columns of writing, which contain 28 lines, measure $8.5 \times 2.5 \mathrm{~cm}$, so each line of lettering is at most $3 \mathrm{~mm}$ high, i.e. too small for more than one person to read with ease.

Although the manuscript is of modest size, it surely required a significant outlay on the part of the person who commissioned it: the parchment is of good quality, fine, white and polished; the lettering is even and competent, and the frequent deployment of ligatures suggests an experienced scribe; the ornamental initials, executed in red and blue, are elaborate, varied and delicate; there are figural inserts on $\mathrm{f}$. $1 \mathrm{r}$ and f. 381v, and polychrome decorations with some use of gold on f. 286v, f. 271v, f. 272r and 278r (TADIN 1953: 152).

Yet the evidence for actual use of the manuscript is ambiguous. On the one hand it has been read at least once: numerous annotations have been added throughout, sometimes over erasures, more often in the margins, in a different, slightly larger hand and rather paler brown ink. These are mostly minor corrections or insertions of missing text, though occasionally the annotator has added a comment, notably on f. 303v to S. John's refutation of the Ebionite heresy. On the other hand, while the parchment is slightly distorted around the outer upper corners, perhaps through damage by water, there is little sign 
of the wear that comes from repeated reading; the discoloration on a few folios near the end is probably due to the use of inferior parchment at that point (pace TADIN 1953: 152).

A plausible factor in the neglect of this manuscript by potential users, as by modern scholars, is its tendency to compression: some texts appear in abbreviated form (BADURINA STIPČEVIĆ 2006: 30-31; BADURINA STIPČEVIĆ 2009: 10-11; BADURINA STIPČEVIĆ 2010: 47; BADURINA STIPČEVIĆ 2016: 421), and the psalter included in the breviary is so far from complete that its value in text-critical study has been characterized as negligible (VAJS 1916: ix) or at best limited for purposes of quantitative analysis (ŠIMIĆ 2000 : 118-120). ${ }^{1}$ The presentational and textual peculiarities of the psalter in MS 172 do, however, have implications for its intended use, and they will therefore be the focus of the following observations.

\section{ORGANIZATION OF THE PSALTER}

Another shared characteristic of the liturgical compendia is that they assist the recitation of the office hours through the week by inserting not only invitatoria, verses and antiphons, but also hymns and canticles at the appropriate points in the psalter (VAJS 1910: xxxiii-xxxiv; VAJS 1948: 42; GRABAR 1984: 172-173), rather than listing them separately, as in manuscripts which contain the breviary only (NAZOR 1977: 31; ŠIMIĆ 2014: 198-204). In MS 172 this practice is carried to the point of disrupting the order of psalms in the psalter. So ps. 50 does not appear in sequence between pss. 50 and 52; instead its incipit is provided for Lauds, together with those of pss. 62 and 148 and of the psalm for the day. Pss. 117 and 118 appear after ps. 120, because Prime, Terce, Sext and None are located after Monday Vespers. Moreover, even where the psalms are listed in the usual order, their presentation is not uniform: they may be written out in full, or cited in alternating versicles, or indicated by incipit only. The effect of these presentational peculiarities can be seen in the listing below. ${ }^{2}$

\subsection{Liturgical psalter in $M S 172$ (omitting invitatoria, verses and antiphons)}

f. 188v Sunday Matins: pss. 1-8 incipits; ps. 9 in full; ps. 10 incipit; pss. 11-13 in alternation; pss. 14-16 incipits; ps. 17 in full; pss. 18-20 incipits;

1 I am grateful to Marinka Šimić for allowing me to consult her unpublished dissertation.

2 I am much indebted to John Harper for advice on the structure of the liturgical psalter; any errors are of course my responsibility. 
f. 191r Sunday Prime: ps. 21 in full; pss. 22-25 incipits;

f. 192r Monday Matins: Snom 'nasiceni (Somno refectis) in full; pss. 26 incipit; pss. 27-30 in full; ps. 31 incipit; pss. 32-33 in alternation; pss. 34-36 in full; ps. 37 incipit;

f. 196v Monday Lauds: pss. 50, 5, 62 incipits; Ispvm se thê $g \bar{i}^{3}$ (Canticle I, Is. 12:1-6) in full; ps. 148 incipit; f. 197r Svatnie stvi oče (Splendor paternae gloriae) in full;

f. 197r Tuesday Matins: Pričest̄nče otačaskie st̄lsti (Consors paterni luminis) in full; ps. 38 in full; ps. 39-42 incipits; ps. 43 in full; pss. 44-45 incipits; ps. 46 in alternation; ps. 47 incipit; pss. $48-49,51$ in full;

f. 200r Tuesday Lauds: pss. 50, 42, 62 incipits; Az'rêx'v prêplvleni d'ni (Canticle II, Is. 38:10-20) incipit; ps. 148 incipit; Petexb d'nev'ni v'zvstitts (Ales diei nuntius) in full;

f. 200v Wednesday Matins: Tvari tvrče prêblgi (Rerum creator optime) in full; ps. 52 in full; ps. 53 incipit; pss. 54-59 in full; ps. 60 initially in full, then in alternation; ps. 61 in full; ps. 62 incipit; ps. 63 in alternation; ps. 64 incipit; ps. 65 in full; ps. 66 incipit; ps. 67 in full;

f. 205r Wednesday Lauds: pss. 50, 64, 62 incipits; Vzradvā se s'rce moe o gêे (Canticle III, I Sam. 2:1-10) in full; f. 205v Noĉ' obličnaê i têmi (Nox et tenebrae et nubila) in full;

f. 206r Thursday Matins: Noĉb tam 'nago dêeniê zatvaraûce (Nox atra rerum contegit) in full; ps. 68 in full; ps. 69 incipit; pss. 70-73 in full; ps. 74 in alternation; pss. 75-79 in full;

f. 213r Thursday Lauds: pss. 50, 89, 62 incipits; Poemb gvê s'lvnê bo prostvi se (Canticle IV, Ex. 15:1-19) in full; f. 214r St̄ostb v'staetb zlt̄naê (Lux ecce surgit aurea) in full;

f. 214r Friday Matins: Ti troice edin'stvo (Tu Trinitatis unitas) in full; pss. 8083 in full; ps. 84 incipit; ps. 85 in full; ps. 86 incipit; pss. 87-89 in full; ps. 90 incipit; ps. 91 in full; ps. 92 incipit; ps. 93 in full; pss. 94-96 incipits;

f. 219v Friday Lauds: pss. 50, 142, 62 incipits; Gī uslišx b s'luxb t'voi (Canticle V, Hab. 3:2-19) in full; ps. 148 incipit; f. 220r Vêc'naê nbsska slva (Aeterna caeli gloria) in full;

f. 220v Saturday Matins: Prêvelikago be dostoêniê (Summae Deus clementiae) in full; ps. 97 incipit; ps. 98 in alternation; ps. 99 incipit; ps. 100 in full; ps. 101 incipit; pss. 102-108 in full;

3 Here and subsequently where the wording of the manuscript is reproduced, abbreviations are retained without expansion, but ligatures are resolved. 
f. 227r Saturday Lauds: pss. 50, 91, 62 incipits; Vanmite nbs̄a êže v'zglû (Canticle VI, Deut. 32:1-43) in full; ps. 148 incipit; f. 229r Zora ûže rassêvaets (Aurora iam spargit) in full;

f. 229r Sunday Vespers: pss. 109-113 incipits; Sta tvrče (Lucis creator) incipit;

f. 229r Monday Vespers: pss. 114-116, 119-120 incipits; Neizmêr'ni nbs̄s saz'dat̄ $\hat{u}$ (Immense caeli conditor) in full;

f. $229 \mathrm{v}$ [Prime]: ps. 117 in alternation, ps. 118 two incipits; Terce: Nine $\mathrm{nm}^{-}$ sti d $\overline{s e}$ (Nunc sancte nobis Spiritus) incipit, ps. 118 three incipits; Sext: Stroit̄lu (Rector potens) incipit; ps. 118 three incipits; None: Rêči be tvrdo $z ̌ i$ (Rerum Deus tenax) incipit, ps. 118 three incipits;

f. 230r Tuesday Vespers: pss. 121-125 incipits; Zeml'ni veliki sazdat̄lu (Telluris ingens conditor) in full;

f. 230r Wednesday Vespers: pss. 126-130 incipits; Nebski be prêsti (Caeli Deus sanctissime) in full;

f. 230v Thursday Vespers: pss. 131-133 incipits; pss. 134-136 in full; f. 231v Veliki be silni (Magnae Deus potentiae) in full;

f. 232r Friday Vespers: ps. 137 incipit; ps. 138 in alternation; pss. 139-141 in full; ps. 142 incipit; f. 233r Sazdat̄û čski (Plasmator hominis) in full;

f. 233r Saturday Vespers: pss. 143-144 in full; ps. 145 incipit; ps. 146 in full; ps. 147 incipit; f. 234v O ste $i$ bžna troice (O lux beata Trinitas) incipit;

f. 234v Sunday [Lauds] ps. 148(-150), Blte v'sa dīa gña (Canticle VII, Dan. 3:57-88), Te Deum, Magnificat, Benedictus, Nunc Dimittis incipits; Quicumque vult in full.

This treatment of the psalter is clearly based on the assumption that the user would know the majority of the psalms by heart and would need only their incipits to identify which ones to recite. The question then arises why some psalms are excluded from this assumption.

\subsection{Psalms in alternation}

As indicated above, twelve psalms are presented in alternating versicles. In instances where each verse falls naturally into two halves, e.g. in pss. 32 33 , an incipit, marked with a rubricated initial letter, is provided for the first half. Where the verse structure is more variable, however, the distribution of incipits does not always coincide with the usual starting-points of verses. The effect of this can be seen in the following examples, where the versicles which make up verses are indicated by superscript letters: 


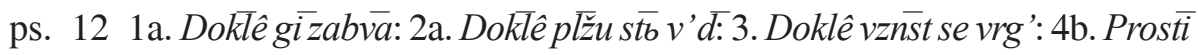
oči moi eda kog: 5b. Stužâû́ mi vrzi moi: 6b. V'zraduet se srce moe:

ps. 63 2a. Us $\overline{l s ̌ i}$ gi gls $\overline{l s}_{\text {moi: }}$ 3a. Pok'rii me ot san'ma: 4a. Iže izoštriše êk or: 5. Sbstrlati v'tainêx': 6b. Ut'vrdiše sbê s'lk: 7a. Is 'pitaše bezknie: 7c.

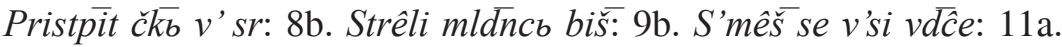
Vzvstit'se prvdnk o g:

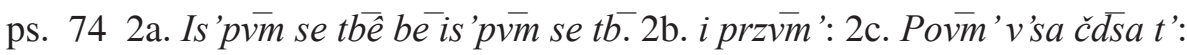
4a. Rastaê se ži vsi: 5a. Rx' zknnoprêstupnkomb: 6a. Ne v'znoste na

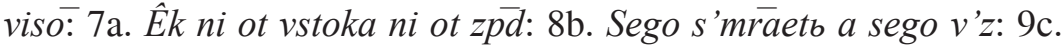
I ukloni se ot sêe vb onu: 10a. Az že v'zraduû se v': 11a. I v'se roge

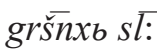

ps. 98 1a. Gb v'cri se da gnêv: 2a. Gb v' sionê veli: 3a. Da is'pvīet'se: 4b. Ti ugotova pravinû: 5a. V'znosite ga ba n⿳亠口冖: $6 \mathrm{a}$. Moisêi i êrunb v' erê: 6c. Prizivaxu gā i ta: 7b. Êk xranaxu svêdñ: 8a. Gī be ti poslušaše: 9a. Vznosite gä bāns:

In ps. 60 the whole of the first verse and the beginning of the second are written out, followed by slightly haphazard alternating text thereafter. This inconsistency may be an indication that the scribe was copying selectively from an exemplar which contained the psalm in full, rather than relying on his knowledge or memory of its antiphonal recitation.

This alternating method of presentation could be taken for a more elaborate type of aide mémoire to help the reader through space-saving abbreviations of the psalms. However, such an explanation seems unlikely: the psalms in question range in length from 6 to 29 verses, but the majority are not longer than 11 verses, so they present no greater challenge to the memory than many of the psalms for which only initial incipits are provided. An alternative and more plausible interpretation is that the incipits to versicles were intended as prompts to guide the user through antiphonal recitation of pss. 11-13, 32-33, 46, 60, 63, 74, 98, 117 and 138, and that the missing versicles were to be supplied in response, whether by another individual or by a congregation.

\subsection{Psalms, canticles and hymns in full}

Length is however a possible factor in the selection of psalms written out in full. Of the 75 psalms, plus the 11 sections of ps.118, for which only initial incipits are given, 33 have less than 10 verses, while only 10 have more than 16 verses and the longest have 29 verses (pss. 101, 148-150). By contrast, 
out of 62 psalms which appear in full, only 6 have less than 10 verses, while 37 have more than 16 verses and the longest has 72 verses (ps. 77). Thus the majority of these psalms placed a burden on the memory which was obviated by writing the text out in extenso. The same consideration may have applied to some of the canticles, particularly the lengthy Canticle VI. The issue of memorization may also be relevant to the full citation of the Old Testament canticles for an additional reason: MS 172 contains the more recent translation from Latin which appears in later breviaries such as the second breviary from Novi (NAZOR 1977: 318-320), rather than the traditional version based on Greek which was still to be found in breviaries of the 14th century (VAJS 1916: 192-204; ŠIMIĆ 2014: 198-203). A reader familiar with the older translation might have required the full text of the revised one. In this connexion it may be significant that most of the office hymns are likewise written out in full; only those most frequently used are indicated by incipit, while those for Sunday Matins and Lauds are omitted. It could be illuminating to know how long the version of the hymns in MS 172 had been in use, and whether it belongs to the more innovative southern tradition (TANDARIĆ 1993: 32).

Yet ease of recall can hardly be the sole motivating factor in the choice between incipit or full text. On the one hand, some of the psalms which appear in full are relatively short and could surely be memorized without difficulty. On the other hand, only the incipit of Canticle II is supplied, although the revised version is undoubtedly intended here, as in the other canticles: it contains the phrase $v$ prêplvleni d'ni, rendering in dimidio dierum, in place of the older reading v'visote dni, which follows the wording of the Septuagint (VAJS 1916: 192; ŠIMIĆ 2014: 198). So the variable presentation of the psalms, canticles and hymns in MS 172 must have been motivated by additional considerations, whether relating to local practice or to the preference of the individual by whom or for whom the manuscript was written.

\section{TEXTUAL PECULIARITIES OF THE PSALTER}

Even in its incomplete state, the text of the psalms in MS 172 offers sufficient evidence to support three significant conclusions. Firstly, although this is still in large part the version, translated from Greek and lightly edited on the basis of Latin, which is found in 14th-century breviaries, supplementary Latin influence can occasionally be detected:

f. 207r ps. 68:24 i hrbt ih' vinu sag'ni se, following semper incurva in place of the older wording otnudb slomi se (VAJS 1916: 84; ŠIMIĆ 2014: 159); 
f. 232v ps. 140:4 i ne pričeĉu se, perhaps prompted by Latin communicabo in this verse, where more conservative manuscripts have $s b c ̌ t u(t) s e$, which

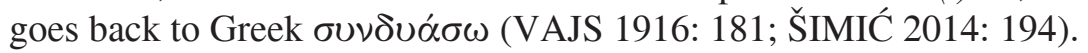

Secondly, erratic copying, either by the scribe of $M S 172$ or in the production of his exemplar, occasionally makes the text defective to the point of unintelligibility. The interventions of the annotator removed some defects, but left others uncorrected, and did not engage with the third textual peculiarity, the prevalence of non-standard readings - banalizations and reminiscences - which tend to occur when a scribe's memory of a familiar text distracts his attention from the exemplar before his eyes (MACROBERT 2008). The evidence for inattentive copying and incomplete correction is reviewed in detail below.

\subsection{Corrections}

The marginal corrections made by the scribe and the annotator can readily be distinguished by differences in lettering and colour of ink. They are written to be clearly legible and are related to the text by the use of reference points. The appearance of careful checking is belied, however, by the sparse occurrence of corrections in this part of the manuscript: it is in fact little more than perfunctory.

\subsubsection{Corrections by the scribe}

The scribe's marginal corrections are minimal: on f. 197v he added the incipit of ps. 40, on ff. $229 \mathrm{v}-233 \mathrm{r}$ verses of the Magnificat and the incipits of pss. 130 and 125; but he corrected only a couple of his numerous omissions, by adding f. 209r ps. 73:2 isprva and f. 214v ps. 80:6 ne zna.

\subsubsection{Corrections by the annotator}

The annotator took a rather more careful approach. In several places he wrote in the margin a verse or versicle which the scribe had omitted: f. 192r ps. 21:26b; f. 197v ps. $38: 9$; f. 209r ps. $73: 11$; f. 217 r ps. $88: 40$; f. $221 \mathrm{r}$ ps. 102:20c; f. 223v ps. 104:35b; f. 233v ps. 144:2. He added an antiphon on f. $214 \mathrm{r}$. He also used the margins occasionally to add words missing from the text: f. 207v ps. 70:17 nauči me, but without the relative pronoun imže which the text requires; f. 210 r ps. $76: 7$ noĉi $\hat{u} ;$ f. $217 \mathrm{v}$ ps. $88: 32$ ne sranetb and ps. 
88:39 otrinu; f. 233r-v ps. 143:1 [oplče]nie, an incomplete correction. His notion of linguistic norm seems to have been slightly different from that of the scribe, because he added a superscript letter to the aorist form in f. $218 \mathrm{r}$ ps. 88:50 kle ${ }^{t}$ 'se; but he left unaltered occasional minor variants, such as idiosyncratic changes in verbal prefixation (ŠIMIĆ 2000: 73-74).

In a small number of instances the annotator introduced corrections into the body of the text. Because these are written over erasures, it is not clear what errors they correct, but their effect is to restore the standard wording:

f. 217v ps. 88:32 oprv̄̄aniê moê os 'kvrnetb. i zapov̄idi moe

f. $218 \mathrm{v}$ ps. $91: 8$ prozbrutb

f. 219r ps. 93:16 na tvorecee bezakonie; ps. 93:23 imb gb po bezkoniemb ihb.

\subsection{Uncorrected errors}

However, there is a considerable number of places where the annotator neglected to reinstate the standard text of the psalms. These fall into two more or less distinct categories: straightforward copying errors which simply reflect the scribe's visual reaction to his exemplar, and textual deviations which arise from the interference of habit and memory in the copying process. Errors of the first kind can probably be attributed to the scribe who wrote $M S 172$; the second type of mistake may either be his responsibility or be inherited from his exemplar.

\subsubsection{Copying errors}

Mechanical copying errors are not frequent in the psalter of $M S 172$, but they do occur. For instance there is a textbook example of saut du même au même:

f. 224v ps. 105:42-43 ... smêrišse se pod'rkmi ihb. m'nožicê̂ izbv̀i e. ti že prog'nêvaeš i s'vêtom's s'voimb. i s'mêriš se pod' rkmi ihb. m'nožicêu iz'bvi e. ti že prog'nêvaše i svêtom'svoimb. i s'mêrišse se v' bzkni s'voihb

When the scribe reached the word s'meriš se in verse 43, he confused it with the same word in verse 42 and so copied out the preceding portion of text a second time before continuing to the end of verse 43 . The same mechanism, though with the opposite result, was probably the cause of a lacuna in the Croatian Church Slavonic version of Ales diei nuntius on f. 200r: the translation of the six lines between the two instances of sobrii in the Latin hymn is 
missing, presumably because the scribe's eye jumped from the first instance of trêzvê in his exemplar to the second one.

Confusion may occur between letters of similar form in Glagolitic, as where the word hlmêhb is misread as glumêhb:

f. 212r ps. 77:58 prog'nêvǐse i v' glumêhb s'voih'

Text may be incorrectly divided:

\section{f. 226r ps. 107:12 ne li ti otrinoveni b $\breve{s e}$}

Here the expected reading, $o^{t}$ rinuvb $n i$, has been misinterpreted as a passive participial form, $t i$ has been taken as a plural demonstrative governing it rather than as the 2 nd person singular pronoun, and the corruption has been completed by turning $\overline{b e}$ from the vocative 'O God' into an abbreviation of the 3rd person plural auxiliary verb. This series of distortions arose from a reading of the text which made no reference to how it would sound in recitation.

\subsubsection{Substantive omissions}

Words and phrases may be omitted from the text for a variety of reasons, for instance because they are not essential to the sense (e.g. possessives) or because they are easily overlooked (e.g. the conjunction $i$ and the homophonous accusative form of the 3 rd person pronoun). When omission undermines meaning, the most likely cause is mechanical error on the part of a copyist who has failed to go back to the right place in the text, as in f. $197 \mathrm{v}$ ps. $38: 7$, where the verb hoditb has been left out of its clause. Explanation is more problematic where the text still makes sense, albeit a different sense, when a whole phrase or clause is left out, as in the following examples: ${ }^{4}$

f. 191r ps. 17:45 [slgaše mi]

f. 191v ps. 21:15 [bis srce moe]

f. 196v ps. 36:40 [i izmetb e ot grêšnikb]

f. 199r ps. 48:15 [smrtb upasetb e]

f. 224r ps. 105:39 [i oskvrni se v dêlêhb ihb].

${ }_{4}$ Here and in subsequent illustrations the expected readings are supplied in square brackets from the Academy breviary (ŠIMIĆ 2014). 
These could again be straighforward copying errors where the scribe's eye skipped a line, but they could equally be due to lapses in memory by someone reproducing a text which he knew well but not perfectly.

\subsubsection{Banalizations}

A similar indeterminacy may apply to banal lexical substitutions. Where one word has been replaced by another of similar appearance which fits the context as well or better, it is impossible to determine whether the scribe has actually misread his exemplar or simply written what he expected to see, as in the following instances: ${ }^{5}$

f. 189r ps. 9:23 uvezaûtb v'sêtêhb [svêtêhb] eže pomšlaûtb

f. 193r ps. 29:13 i ne umalûu [umilû] se

f. 224r ps. 105:25 i porptaše v's sêhb [selêhb] s'voihb.

It is natural to expect people to get caught in nets rather than in counsels, to wish to avoid belittlement rather than compunction, to murmur in their words or discourse rather than in their settlements; the use of abbreviations merely increases the risk of reading what one expects rather than what is actually on the page.

Banalization, the tendency to substitute commonplace wording for less usual expressions, may also manifest itself through changes in grammatical form:

f. 219r ps. 93:15 i držet' [držeĉe] $\hat{u} v$ 'si pravi s'rcemb

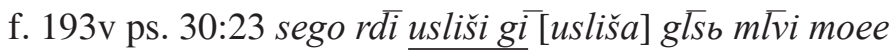

f. 194v ps. 34:11 v'staše [vstaûce] ñme s'vd̄teli neprvd̄ni

f. 201v ps. 55:13 obêti t'voe eže v'zdahb [vzdamb]

The most striking instances of banalization result not from misplaced visual associations or careless reading but from familiarity with the themes, images and phraseology which are characteristic of the text:

f. 206v ps. 68:6 be ti uv̄ê bzknie [bezumie] moe

f. 212r ps. 77:59 s'liša bs i prog'nêva se [prêzrê]

f. 219r ps. 93:9 i sazdav'i oko ne vdit [smotrit] $l i$

f. 223r ps. 104:25 v'znenavditi ego [lûdi ego]

f. 232v ps. 140:4 ne ukloni us 'ta moê [srca moego]

$\overline{5}$ Here and in subsequent illustrations the substitute expressions are indicated by underlining. 
Each of these incorrect readings is plausible in context: the psalmist is typically preoccupied with his own lawlessness, with God's wrath and all-seeing presence, with the heathen's hatred of God, with keeping his lips as well as his heart from wrongful words.

Sometimes the likely model for a banalizing reading can be identified elsewhere in the text. So f. 201v ps. 55:14 da ugoû prêd gmb v' mêstê [svêtê] živucihb may have been inspired by pss. 26:13 and 141:6 na zemli živyhb or by ps. 114:9v stranê živucihb, a phrase which is reproduced as direct reminiscence in ps. 55:14 of the Psalterium Sinaiticum (ŠIMIĆ 2000: 98-99). The

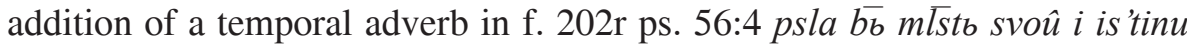
svôิ noĉiu may be an anticipation of pos'pah's'much in the next verse or an approximate reminiscence of ps. 16:3 posêtilb esi noĉiu. The change of wording in f. 204r ps. 65:11 pōžil' esi s'krbb na s'rci [hrbtê] nšmb may reflect an assumption that grief oppresses the heart rather than the back or be an echo of ps. 12:3 dokolê položu [...] bolêznь v š̄ci moemb.

\subsubsection{Reminiscences}

Direct, verbatim reminiscences can also be seen as a type of banalization, but they depend on close familiarity with the words of the text, not just with its subject matter and style, and therefore provide evidence of internal dictation on the basis of memory. At one point in the liturgical psalter of MS 172 the interaction between this process and that of copying from an exemplar is clearly visible, when because of a similarity in wording at the start of Is. 12:2 and Ex. 15:2 a clause from Canticle IV was interpolated into Canticle I. If this was done by the scribe of $M S 172$, he realised his mistake immediately, because the reminiscence is crossed out in the red ink used for rubrication and the text reverts to Canticle I:

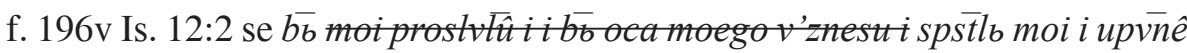
s'tvoru

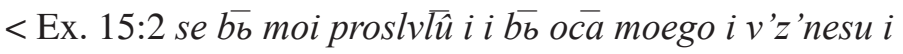

Alternatively the error may already have been present in the scribe's exemplar, in which case he detected it after he had copied it.

Elsewhere, however, reminiscences went undetected. Some are the result of proximate influence from an earlier verse in the same psalm, and so could be regarded as a kind of copying error where the scribe reverts to a phrase written shortly before:

f. 195r ps. 35:5 bezknie i lasti pomisli < ps. 35:4 gli ustb ego bzknie i lsts 
f. $197 \mathrm{v}$ ps. $38: 8$ upostasb moê ničtože ěprêd tbồ $[$ [u tebe estb] < ps. 38:6 $i$ upostasb moê ničtože ě prêd tbồ

f. 207r ps. 70:5 êk ti esi pribêžice [trpênie] moe < ps. 70:3 êk utvrždenie moe i pribižice moe esi ti

This mechanism cannot however account for anticipation of a phrase which occurs later in the given psalm, nor for the transference of phrases from psalms which are widely separated from each other within the psalter:

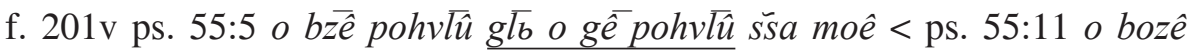

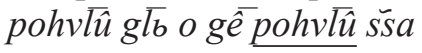

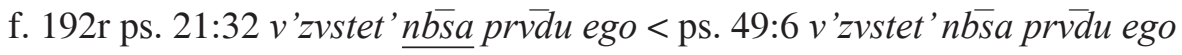

f. 198v ps. 43:25 lice tvoe otvr⿳亠丷⿵冂丶

f. 207v ps. 70:15 usta moê v'zvêstetb hvlu [pravdu] tvoû < ps. 50:17 usta moê vzvêstetb hvalu tvoû

f. 217v ps. 88:47 raz'garaet se êkogan'r'vnie t'voe [gnêvb] < ps. 78:5 razgaraet se êk ognb r'vnie t'voe

f. $218 \mathrm{v}$ ps. 91:6 êk vzvlči se do $n b \bar{s} b$ mIstb t'voê [dêla tvoê] < ps. 56:11 êk

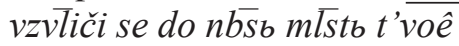

f. 223r ps. 104:22 da naučitb snī $[k n e z i]$ ego êk smō sbe < ps. 89:16 nastavi sni ih

f. 225r ps. 106:11 i svêtb niçago [višnago] razdražiše < ps. 13:6 svitb nêcago pos'rmste

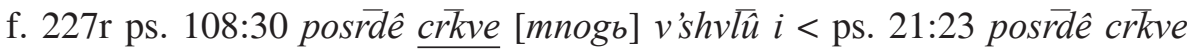
v'spoû te

These are unequivocal reminiscences, the work of a scribe who relied at least in part on his memory of the psalms, not just on reproduction of a written text. Since there are some indications, discussed above in sections 2.2. and 3.2.1., that the scribe who wrote $M S 172$ copied from a fuller version of the psalter and was guided more by eye than by aural memory, it is possible that they were already present in his exemplar.

\section{CONCLUSIONS}

What then is the value of the liturgical psalter in $M S 172$ to the modern investigator? To the textual scholar it must be a source of disappointment and frustration, even if it contains instructive examples of how corruption may arise and be tolerated in a well known text. To anyone interested in the production and use of liturgical books, however, it offers some illuminating insights. It is not, of course, unusual that fine parchment, penmanship and 
ornamentation should go hand in hand with imperfect copying. What is more remarkable is that such expense and pains should be devoted to the production of a manuscript which was only likely to be used by one person. The presentation of the psalter in MS 172 presupposes a user who was confident that he knew more than half of the psalms by heart and that brief prompts, rather than full text, were adequate to his needs. If he wrote the manuscript himself, he relied either on a faulty exemplar or on his own memory even for the psalms which he reproduced in full; if he commissioned the book and corrected it on receipt, he knew the psalms rather better than the scribe did, but by no means perfectly. He had sufficient means to afford a book for his sole use; he was perhaps old enough to need full copies of recently revised canticles; advancing years and failing eyesight may explain why in the event he made little use of a manuscript which is almost miniature in scale. Thereafter the elliptical treatment of key texts would have limited its usefulness to prospective readers who were not as well versed in the psalms as its first owner. Comprehensive textual investigation could yet cast fuller light on the dating, provenance, local liturgical practice and intended use of this enigmatic manuscript.

\section{LITERATURE}

BADURINA STIPČEVIĆ, V. 2006. Knjige o Makabejcima u hrvatskoglagoljskoj književnosti: Prva Knjiga o Makabejcima u hrvatskoglagoljskim brevijarima. Slovo 54-55: $5-126$.

BADURINA STIPČEVIĆ, V. 2009. Knjige o Makabejcima u hrvatskoglagoljskoj književnosti: Druga Knjiga o Makabejcima u hrvatskoglagoljskim brevijarima. Slovo 59: $1-75$.

BADURINA STIPČEVIĆ, V. 2010. Hrvatskoglagoljska Muka svetoga Andrije apostola. Slovo 60: 41-71.

BADURINA STIPČEVIĆ, V. 2016. Hrvatskoglagoljska Pasija svete Lucije. Ricerche slavistiche 14 (60): 417-438.

DU FEU, V. M. 1971. The Glagolitic MSS in the Bodley Library. Slovo 21:301-303 and plate.

GRABAR, B. 1984. Tiskani glagoljski Baromićev brevijar. Slovo 34: 159-180.

HAMM, J. 1953. Review of TADIN 1953. Slovo 3: 118-19.

MACROBERT, C. M. 2008. On the role of memory and oral tradition in the early transmission of the Church Slavonic psalter text. A. Miltenova; E. Tomova; R. Stankova (ed.). Xristijanska agiologija i narodni vjarvanija. Sbornik v čest na st. $n$. s. Elena Koceva. Sofia: Iztok-zapad, 340-55.

NAZOR, A. 1977. II. Novljanski brevijar: hrvatskoglagoljski rukopis iz 1495. Zagreb: Staroslavenski institut. 
ŠIMIĆ, M. 2000. Leksik hrvatskoglagoljskoga psaltira. Doctoral dissertation, Zagreb.

ŠIMIĆ, M. 2014. Akademijin Brevijar HAZU III c 12. Zagreb: Staroslavenski institut.

ŠTEFANIĆ, V. 1970. Glagoljski rukopisi Jugoslavenske akademije. II. dio. Zagreb: JAZU.

TADIN, M. 1953. Glagolitic manuscripts in the Bodleian Library, Oxford. Oxford Slavonic Papers $I V$ : $151-158$ and plates.

TANDARIĆ, J. L. 1993. Hrvatskoglagoljska liturgijska književnost. Zagreb: Kršćanska Sadašnjost - Provincijalat franjevaca trećoredaca.

VAJS, J. 1910. Nejstarší Breviář chrvatsko-hlaholský. Prague: Náklad Král. České Společnosti Naúk.

VAJS, J. 1915. Hlaholské kodexy v Bodlejaně v Oxfordě. Časopis katolického duchovenstva LVI (81): 560-574.

VAJS, J. 1916. Psalterium palaeoslovenicum croatico-glagoliticum. Krk - Prague: Academia palaeoslovenica Veglensis.

VAJS, J. 1948. Najstariji hrvatskoglagolski misal. Djela Jugoslavenske akademije znanosti i umjetnosti 38. Zagreb: JAZU.

Sažetak

\section{Catherine Mary MACROBERT}

\section{ZAPAŽANJA O LITURGIJSKOM PSALTIRU U MS CANON. LITURG. 172 (BODLEYANSKA KNJIŽNICA, OXFORD)}

U tekstu su analizirane strukturne i tekstološke posebnosti psaltira u brevijarskom dijelu glagoljskog rukopisa Canon. liturg. 172 koji se čuva u Bodleyevoj biblioteci. Na osnovi tih posebnosti iznose se dokazi o učestalom korištenju psaltira prilikom učenja teksta napamet i osobnoj liturgijskoj praksi te se ukazuje na mogućnost da je rukopis bio namijenjen specifičnom korisniku.

Ključne riječi: brevijari, pojednostavljenja, kantici, himni, psaltir

Catherine Mary MacRobert

University of Oxford

Oxford (United Kingdom)

catherine.macrobert@1mh.ox.ac.uk 